\title{
Proximate, amino acid, fatty acid and mineral composition of Grey mullet, Mugil cephalus L: A comparative study between the culture and wild resources in different size groups and potential contribution to nutritional security
}

\author{
Syama Dayal ( $\nabla$ syamdayal@rediffmail.com ) \\ ICAR-Central Institute of Brackishwater Aquaculture \\ Rajabdeen Jannathulla \\ ICAR-Central Institute of Brackishwater Aquaculture \\ Kondusamy Ambasankar \\ ICAR-Central Institute of Brackishwater Aquaculture \\ Kumaraguru Vasagam \\ ICAR-Central Institute of Brackishwater Aquaculture \\ Koyadan Vijayan \\ ICAR-Central Institute of Brackishwater Aquaculture
}

\section{Research Article}

Keywords: Amino acid, Cultured, Daily value, Fatty acid, Mineral, Mugil cephalus, Wild

Posted Date: December 9th, 2020

DOI: https://doi.org/10.21203/rs.3.rs-114155/v1

License: @) (1) This work is licensed under a Creative Commons Attribution 4.0 International License. Read Full License 


\section{Abstract}

Mugil cephalus is widely distributed across all oceans and it is a potential candidate species for aquaculture. Nutrient profiling in terms of proximate, amino acid, fatty acid and mineral composition was analyzed in muscle tissue of $M$. cephalus sourced from culture and wild with four different sizes (100-150 g, $151-250 \mathrm{~g}, 251-500 \mathrm{~g}$ and $>500 \mathrm{~g}$ ). Results of proximate composition revealed that both the factors (resource and size) had a significant $(\mathrm{P}<0.05)$ effect on moisture, crude lipid, total ash and gross energy but not on crude protein and crude fibre. Though the amino acid composition was not influenced by resource and size, the level of essential amino acids of ideal protein was higher than the recommended level by FAO/WHO for phenylalanine (43.29-45.60\%), tryptophan (36.60-39.02\%) and lysine (33.61-41.51\%). Fatty acids like C14:0, C16:0, C18:0, C18:1c, C18:2c and yC18:3 was significantly (P<0.05) high in cultured species compared to wild caught fish, irrespective of the size groups and the reverse was true for aC18:3, C20:4 and C20:5. The amount of calcium, phosphorus, sodium and potassium was significantly $(P<0.05)$ higher by $10.68,5.82,9.31$ and $6.93 \%$ in wild caught fish than its counterpart. The potential contribution of this fish to nutritional security in terms of its daily value (DV) was calculated for one serving of $100 \mathrm{~g}$ fish to adult human being. Results revealed that lysine, methionine, threonine, tryptophan and EPA + DHA were considered as outstanding nutrients in this fish, irrespective of their source and size as their DV crossed $>70 \%$. Similarly, isoleucine, leucine, phenylalanine and valine could also able to meet $50-70 \%$ of the daily needs of adult human indicating the nutritional richness of both wild and cultured $M$. cephalus regardless of its size.

\section{Introduction}

Fish is a relatively cheaper food material with higher quality than the meat sources, which plays a crucial role in global Food Nutrition Security (FNS), especially in low and middle income countries ${ }^{1}$. Fish serves a healthy, safe, nutritious and balanced diet to human, as it is rich in valuable nutrients (protein with essential amino acids (EAA), long chain n-3 polyunsaturated fatty acids (LC n-3 PUFA), minerals mainly micro elements). Therefore, its consumption plays an important role in reducing global burden of disease. Alasalvar et al ${ }^{2}$ stated that LC $n-3$ PUFA cannot be synthesized in human and should be supplemented by diet. As this is rich in fish, helps in neural development in both utero and first few years after birth in infants ${ }^{3}$. In addition, consuming PUFA plays a vital role in controlling various diseases and disorders like aggression, arrhythmias, cancer, coronary heart failure, depression, hypertension, inflammation, psoriasis, etc ${ }^{4}$. WHO ${ }^{5}$ and FAO/IFAD/WFP 6 reported that around 870 million peoples are affected by protein-energy malnutrition globally and it is nearly $80 \%$ in developing countries alone. As fish is an important protein source, its prolonged use can reduce a lethal form of malnutrition ${ }^{7}$. Likewise, certain functional amino acids involved in the process of wound healing and act as an anti-mutagenicity and anti-oxidant ${ }^{8}$. Similarly, element content of fish would be most beneficial to human, as they play vital roles in various metabolic pathways ${ }^{9}$.

The capture fisheries production has become static (96.4 million tonnes in 2018), which could not meet the demand for fish due to the geometric growth of global population ${ }^{10}$. However, the expansion of aquaculture production (114.5 million tonnes in 2018) could able to bridge the gap between the demand and supply worldwide. $\mathrm{FAO}^{10}$ reported that the aquaculture sector grown by $527 \%$ in 2018 compared to 1990 , which alone contributes by $54.46 \%$ of the total global fish production with currently valued at USD 263.6 billion ${ }^{11}$. As in the world, Indian aquaculture sector has also been evolved with considerable diversification in terms of species. Though the Indian major carps have dominated, certain other fishes have also been cultured in India traditionally. One among them is Grey mullet (Mugil cephalus L), and it is predominant in the state of West Bengal, Andhra Pradesh, Tamil Nadu and Kerala in India. M. cephalus has a very wide distribution in all the oceans, estuaries and brackishwater of tropical and sub-tropical regions from $42^{\circ} \mathrm{N}$ to $42^{\circ} \mathrm{S}$. Their catches have increased as a result of a growing market in the south-eastern United States, Gulf coast, Asian and Mediterranean markets with good nutrient profiles ${ }^{12}$. Jannathulla et al ${ }^{13}$ reported that the nutrient composition of aquatic animals greatly varies, not only between the species and even within the groups, which is mainly due to the variation in feed and biological resource present in the waterbody. In addition, various factors would also influence the nutrient profiling of fish, the most important are age and sources of collection ${ }^{14}$. In this context, various methods have been developed by Nutrition Labelling and Education Act (NLEA) in the United States and Association of Analytical Chemist (AOAC) for documenting fundamental knowledge on the nutritional quality of aquatic species. Several studies have already been reported the nutrient compositions of various fin-fishes collected from wild and culture ${ }^{14-18}$. However, the available data on $M$. cephalus is scarce yet to date. Hence, the present study is aimed to investigate the nutrient composition of muscle tissue in $M$. cephalus collected from two different sources with four varied size groups. This baseline data would help to facilitate the consumers to realize about the nutritional quality of this fish, by which they could assure about their health, immunity and fitness against the lifestyle disease, which is of great significance to increase the market value of this fish in India and around the globe in the future.

\section{Results}

Proximate composition of $M$. cephalus sourced from both culture and wild with different size groups (Table 1) revealed that both the factors (resource and size) had a significant $(\mathrm{P}<0.05)$ effect on moisture, crude lipid, total ash and gross energy but not on crude protein and crude fibre level. The moisture content was significantly $(P<0.05)$ high in wild caught fish $(74.23 \%)$ compared to culture one $(72.32 \%)$ and was gradually decreased from $75.08-70.57 \%$ with increasing size. Wild caught fish had $2.54 \%$ of crude lipid and was more than doubled in cultured species (5.44\%). Though the lipid content was almost similar in the groups categorized under $100-150 \mathrm{~g}$ and $151-250 \mathrm{~g}(2.44-2.75 \%)$, its level was higher by $36 \%$ and $141 \%$ in $251-500 \mathrm{~g}$ and $>500 \mathrm{~g}$ groups, respectively. Total ash content found to be high $(\mathrm{P}<0.05)$ in wild caught fish compared to the cultured one, whereas, its level was not affected in the groups had a weight beyond $151 \mathrm{~g}$. Gross energy was significantly $(P<0.05)$ high in cultured fish $(133.03 \mathrm{Kcal} / 100 \mathrm{~g})$ than wild fish $(110.12 \%)$ and was gradually $(P$ $<0.05$ ) increased from $107.46-145.27 \mathrm{Kcal} / 100 \mathrm{~g}$ with increasing size. 
Table 1

Proximate composition (\% wet weight basis) of different size group of $M$. cephalus collected from culture and wild resources.

\begin{tabular}{|c|c|c|c|c|c|c|c|}
\hline \multirow[t]{2}{*}{ Particulars } & \multicolumn{6}{|c|}{ Proximate composition } & \multirow{2}{*}{$\begin{array}{l}\text { Gross energy } \\
\text { (Kcal/100 g) }\end{array}$} \\
\hline & Moisture & Crude protein & Crude fat & Crude fibre & NFE & Total ash & \\
\hline
\end{tabular}

\begin{tabular}{|llllllll|}
\hline Resource (A) & \multicolumn{7}{l|}{} \\
\hline Culture & $72.32^{\mathrm{b}}$ & $20.40^{\mathrm{a}}$ & $5.44^{\mathrm{a}}$ & $0.11^{\mathrm{a}}$ & $0.48^{\mathrm{b}}$ & $1.20^{\mathrm{b}}$ & $133.03^{\mathrm{a}}$ \\
\hline Wild & $74.23^{\mathrm{a}}$ & $20.67^{\mathrm{a}}$ & $2.54^{\mathrm{b}}$ & $0.12^{\mathrm{a}}$ & $1.00^{\mathrm{a}}$ & $1.42^{\mathrm{a}}$ & $110.12^{\mathrm{b}}$ \\
\hline Size (B) & & & & & & \\
\hline $100-150 \mathrm{~g}$ & $75.08^{\mathrm{a}}$ & $20.39^{\mathrm{a}}$ & $2.44^{\mathrm{c}}$ & $0.11^{\mathrm{a}}$ & $0.86^{\mathrm{a}}$ & $1.17^{\mathrm{b}}$ & $107.46^{\mathrm{c}}$ \\
\hline $151-250 \mathrm{~g}$ & $74.17^{\mathrm{ab}}$ & $20.94^{\mathrm{a}}$ & $2.75^{\mathrm{c}}$ & $0.13^{\mathrm{a}}$ & $0.65^{\mathrm{a}}$ & $1.31^{\mathrm{a}}$ & $111.71^{\mathrm{c}}$ \\
\hline $251-500 \mathrm{~g}$ & $73.37^{\mathrm{b}}$ & $20.45^{\mathrm{a}}$ & $4.14^{\mathrm{b}}$ & $0.11^{\mathrm{a}}$ & $0.56^{\mathrm{a}}$ & $1.34^{\mathrm{a}}$ & $121.85^{\mathrm{b}}$ \\
\hline$>500 \mathrm{~g}$ & $70.57^{\mathrm{c}}$ & $20.36^{\mathrm{a}}$ & $6.63^{\mathrm{a}}$ & $0.11^{\mathrm{a}}$ & $0.90^{\mathrm{a}}$ & $1.42^{\mathrm{a}}$ & $145.27^{\mathrm{a}}$ \\
\hline P-value & & & & & & \\
\hline A & $<0.001$ & 0.203 & $<0.001$ & 0.373 & 0.038 & $<0.001$ & $<0.001$ \\
\hline B & $<0.001$ & 0.167 & $<0.001$ & 0.500 & 0.690 & 0.005 & $<0.001$ \\
\hline AxB & 0.011 & 0.549 & $<0.001$ & 0.847 & 0.700 & 0.437 & $<0.001$ \\
\hline SEM ( \pm$)$ & 0.269 & 0.133 & 0.097 & 0.001 & 0.179 & 0.006 & 9.337 \\
\hline CV $(\%)$ & 0.931 & 2.335 & 10.255 & 20.535 & 74.479 & 7.629 & 3.308 \\
\hline
\end{tabular}

Among the essential amino acids (EAA), leucine found to be high followed by lysine and arginine, while the least values were noticed with histidine and tryptophan, whereas in non-essential amino acids (NAA), the highest values were observed for glutamic acid followed by aspartic acid (Table 2). However, no significant differences were observed not only between the resources and also among the size groups. Ideal protein (IP) level, calculated based on the FAO/WHO/UNU ${ }^{19}$ values, showed that though there was no much of difference between culture and wild fish, the IP level was increased for all the tested amino acids than the FAO/WHO/UNU ${ }^{19}$ recommended values except valine (Fig. 1). The IP level given by FAO/WHO/UNU ${ }^{19}$ for Phe + Tyr, lysine and tryptophan are 60,55 and $10 \mathrm{mg} / \mathrm{g}$, respectively, and was increased by $47.81,35.73$ and $39.17 \%$ in cultured fish and by $41.41,39.50$ and $36.33 \%$ in wild caught fish. However, the increase was ranged between 11 and $15 \%$ for isoleucine, leucine and threonine. A similar trend was noticed in the fish categorized under different size groups. Though the IP level of valine was decreased around by $10 \%$, irrespective of the resource and size, the computed EAAI, based on FAO/WHO/UNU ${ }^{19}$ values, did not have any influence on them and was in the range of 0.9251-0.9719 (Fig. 2). Regression performed between culture and wild caught fish, irrespective of the size groups was positively correlated and the equation was $y=0.005 \times 2-0.0042 x+0.9536, R^{2}=0.184$ for cultured fish and $y=0.002 \times 2$ $0.0049 x+0.9564, R^{2}=0.2696$ for wild caught fish (Fig. 2). 
Table 2

Amino acid composition (\% wet weight basis) of different size group of $M$. cephalus collected from culture and wild resources.

\begin{tabular}{|c|c|c|c|c|c|c|c|c|c|c|c|c|c|c|c|c|}
\hline \multirow[t]{2}{*}{ Particulars } & \multicolumn{16}{|c|}{ Essential amino acids } \\
\hline & Arg & His & lle & Leu & Lys & Met & Phe & Thr & Trp & Val & Ala & Asp & Cyt & Glu & Gly & PI \\
\hline \multicolumn{17}{|l|}{$\begin{array}{l}\text { Resource } \\
\text { (A) }\end{array}$} \\
\hline Culture & 1.38 & 0.26 & 0.93 & 1.60 & 1.52 & 0.76 & 1.09 & 0.93 & 0.28 & 0.92 & 1.30 & 2.06 & 0.05 & 3.14 & 0.95 & 0. \\
\hline Wild & 1.42 & 0.26 & 0.93 & 1.61 & 1.59 & 0.81 & 1.04 & 0.92 & 0.28 & 0.93 & 1.31 & 2.05 & 0.05 & 3.23 & 0.92 & 0. \\
\hline \multicolumn{17}{|l|}{ Size (B) } \\
\hline $\begin{array}{l}100- \\
150 \mathrm{~g}\end{array}$ & 1.35 & 0.26 & 0.90 & 1.57 & 1.50 & 0.74 & 1.06 & 0.91 & 0.28 & 0.91 & 1.28 & 2.00 & 0.05 & 3.16 & 0.89 & 0 . \\
\hline $\begin{array}{l}151- \\
250 \mathrm{~g}\end{array}$ & 1.44 & 0.28 & 0.96 & 1.64 & 1.58 & 0.79 & 1.10 & 0.94 & 0.29 & 0.93 & 1.34 & 2.10 & 0.05 & 3.21 & 0.98 & 0 . \\
\hline $\begin{array}{l}251- \\
500 \mathrm{~g}\end{array}$ & 1.41 & 0.25 & 0.93 & 1.64 & 1.55 & 0.80 & 1.05 & 0.93 & 0.28 & 0.94 & 1.29 & 2.07 & 0.05 & 3.19 & 0.93 & 0 . \\
\hline$>500 \mathrm{~g}$ & 1.40 & 0.27 & 0.92 & 1.58 & 1.59 & 0.81 & 1.04 & 0.93 & 0.28 & 0.91 & 1.31 & 2.06 & 0.05 & 3.17 & 0.94 & 0. \\
\hline \multicolumn{17}{|l|}{ P-value } \\
\hline$A$ & 0.127 & 0.936 & 0.996 & 0.766 & 0.076 & 0.329 & 0.355 & 0.749 & 0.830 & 0.452 & 0.701 & 0.795 & 0.184 & 0.184 & 0.482 & 0. \\
\hline B & 0.059 & 0.335 & 0.387 & 0.480 & 0.260 & 0.721 & 0.847 & 0.930 & 0.969 & 0.551 & 0.332 & 0.358 & 0.810 & 0.943 & 0.232 & 0. \\
\hline$A \times B$ & 0.665 & 0.353 & 0.769 & 0.746 & 0.827 & 0.799 & 0.961 & 0.858 & 0.849 & 0.477 & 0.945 & 0.892 & 0.122 & 0.643 & 0.678 & 0. \\
\hline SEM $( \pm)$ & 0.001 & 0.001 & 0.002 & 0.006 & 0.004 & 0.008 & 0.011 & 0.004 & 0.001 & 0.001 & 0.001 & 0.005 & 0.001 & 0.014 & 0.003 & 0 . \\
\hline CV (\%) & 3.635 & 8.295 & 5.864 & 6.146 & 5.137 & 15.403 & 12.790 & 8.865 & 8.660 & 4.857 & 3.808 & 4.469 & 10.003 & 4.830 & 8.277 & 12 \\
\hline
\end{tabular}

Both resources and size have highly influenced $(P<0.05)$ the tissue fatty acid composition as depicted in Table 3 . Among the fatty acids presented, $C 16: 0$ was abundant and accounted about $35-40 \%$ of total fatty acids, while the least was noticed with both $\mathrm{Y}$ and a C18:3. Fatty acids like C14:0, C16:0, C18:, C18:1C, C18:2c and $y C 18: 3$ was significantly $(P<0.05)$ high in cultured species compared to wild caught fish and the reverse was true for aC18:3, $\mathrm{C} 20: 4$ and $\mathrm{C} 20: 5$, whereas there was no significant difference for C22:6 between culture $(120.07 \mathrm{mg} / 100 \mathrm{~g})$ and wild $(118.45 \mathrm{mg} / 100 \mathrm{~g})$ collected fish. The size of the fish had a direct proportion to the muscle fatty acid composition, including eicosapentaenoic acid (EPA) and docosahexaenoic acid (DHA). However, the ratios of $n-6 / n-3$ and DHA/EPA were found to be high in 151-250 g and 251-500 g groups, respectively. Fatty acids like C14:0, yC18:3, C20:4 and C20:5 were significantly ( $<$ < 0.05 ) increased with increasing fish size, whereas there was no significant difference for $\mathrm{C} 16: 0, \mathrm{C} 18: 0, \mathrm{C} 16: 1, \mathrm{C} 18: 2 \mathrm{c}$ and $\mathrm{C} 22: 6$ between the fish categorized into 100-150 g and 151-250 g groups. Similarly, no significant difference was observed for C18:1c and C18:2c between the groups had a body weight of $151-250 \mathrm{~g}$ and $251-500 \mathrm{~g}$. Among the presented fatty acids, the difference was very conspicuous for $\mathrm{C} 16: 0$ and was increased by $1103.61 \mathrm{mg} / 100 \mathrm{~g}$ in cultured fish compared to the wild one. Among the size groups, the increase was $1187.39,1105.80,730.23 \mathrm{mg} / 100 \mathrm{~g}$ in fish with a body weight of $>500 \mathrm{~g}$ compared to the groups of $100-150 \mathrm{~g}, 151-250 \mathrm{~g}$ and $251-500 \mathrm{~g}$, respectively. 
Table 3

Major fatty acid composition (mg/100 g wet weight basis) of different size group of $M$. cephalus collected from culture and wild resources.

\begin{tabular}{|c|c|c|c|c|c|c|c|c|c|c|c|}
\hline \multirow[t]{2}{*}{ Particulars } & \multicolumn{11}{|c|}{ Major fatty acids } \\
\hline & $\mathrm{C} 14: 0$ & $\mathrm{C} 16: 0$ & C18:0 & C16:1 & C18:1c & C18:2c & YC18:3 & aC18:3 & C20:4 & C20:5 & $\mathrm{C} 22: 6$ \\
\hline \multicolumn{12}{|l|}{ Resource (A) } \\
\hline Culture & $124.76^{a}$ & $1585.87^{a}$ & $453.46^{a}$ & $610.76^{a}$ & $728.27^{a}$ & $455.04^{a}$ & $34.72^{\mathrm{a}}$ & $18.80^{\mathrm{b}}$ & $60.44^{b}$ & $122.31^{\mathrm{b}}$ & $120.07^{a}$ \\
\hline Wild & $71.53^{b}$ & $482.26^{b}$ & $241.65^{\mathrm{b}}$ & $296.28^{b}$ & $111.09^{b}$ & $44.55^{b}$ & $23.30^{\mathrm{b}}$ & $76.53^{\mathrm{a}}$ & $170.36^{a}$ & $149.39^{a}$ & $118.45^{\mathrm{a}}$ \\
\hline \multicolumn{12}{|l|}{ Size (B) } \\
\hline $100-150 \mathrm{~g}$ & $42.32^{d}$ & $602.52^{c}$ & $128.41^{\mathrm{c}}$ & $250.27^{c}$ & $239.98^{c}$ & $149.37^{c}$ & $11.82^{d}$ & $13.80^{d}$ & $33.62^{d}$ & $55.36^{d}$ & $53.40^{c}$ \\
\hline $151-250 \mathrm{~g}$ & $66.43^{c}$ & $684.11^{c}$ & $170.15^{c}$ & $290.39^{c}$ & $342.60^{\mathrm{b}}$ & $198.63^{b c}$ & $21.48^{\mathrm{c}}$ & $32.38^{c}$ & $93.51^{c}$ & $89.23^{c}$ & $72.33^{\mathrm{c}}$ \\
\hline $251-500 \mathrm{~g}$ & $95.18^{b}$ & $1059.68^{b}$ & $396.14^{b}$ & $431.02^{b}$ & $388.37^{b}$ & $224.29^{b}$ & $31.90^{\mathrm{b}}$ & $50.82^{b}$ & $129.59^{b}$ & $151.29^{b}$ & $155.12^{b}$ \\
\hline$>500 \mathrm{~g}$ & $188.63^{a}$ & $1789.91^{\mathrm{a}}$ & $695.50^{a}$ & $842.41^{a}$ & $707.77^{a}$ & $426.90^{\mathrm{a}}$ & $50.83^{a}$ & $93.68^{a}$ & $204.88^{a}$ & $247.53^{a}$ & $196.18^{a}$ \\
\hline \multicolumn{12}{|l|}{ P-value } \\
\hline A & $<0.001$ & $<0.001$ & $<0.001$ & $<0.001$ & $<0.001$ & $<0.001$ & $<0.001$ & $<0.001$ & $<0.001$ & 0.001 & 0.813 \\
\hline B & $<0.001$ & $<0.001$ & $<0.001$ & $<0.001$ & $<0.001$ & $<0.001$ & $<0.001$ & $<0.001$ & $<0.001$ & $<0.001$ & $<0.001$ \\
\hline$A \times B$ & 0.095 & $<0.001$ & $<0.001$ & 0.046 & $<0.001$ & $<0.001$ & 0.072 & $<0.001$ & $<0.001$ & $<0.001$ & $<0.001$ \\
\hline $\operatorname{SEM}( \pm)$ & 127.895 & 11519.650 & 1859.947 & 3583.213 & 2605.150 & 1345.800 & 6.833 & 91.455 & 178.914 & 140.097 & 156.706 \\
\hline CV (\%) & 15.168 & 13.660 & 16.331 & 17.371 & 16.006 & 19.328 & 11.858 & 26.401 & 15.254 & 11.466 & 13.814 \\
\hline
\end{tabular}

The mineral composition of $M$. cephalus sourced from both culture and wild with different size groups is presented in Table 4. Regardless of resource and size, the highest values were found in potassium followed by phosphorus, while calcium, sodium and magnesium were in the range of $10-40 \mathrm{mg} / 100 \mathrm{~g}$. The level of calcium, phosphorus, sodium and potassium in cultured fish was $18.66,185.49,35.76$ and $231.78 \mathrm{mg} / 100 \mathrm{~g}$, respectively, and was significantly $(\mathrm{P}<$ 0.05 ) increased by $10.68,5.82,9.31$ and $6.93 \%$ in wild caught fish. The increasing trend with increasing body weight was noticed for all the four macroelements as mentioned above. However, the amount of magnesium did not vary between the source as well as size. The level of all the micro-elements analysed was $<0.5 \mathrm{mg} / 100 \mathrm{~g}$ and was not influenced by both resources and size.

Table 4

Mineral composition (mg/100 g wet weight basis) of different size group of $M$. cephalus collected from culture and wild resources.

\begin{tabular}{|c|c|c|c|c|c|c|c|c|c|}
\hline \multirow[t]{2}{*}{ Particulars } & \multicolumn{9}{|c|}{ Mineral composition } \\
\hline & $\mathrm{Ca}$ & $\mathbf{P}$ & $\mathrm{Na}$ & $\mathbf{K}$ & $\mathbf{M g}$ & $\mathrm{Cu}$ & $\mathrm{Fe}$ & $\mathrm{Mn}$ & $\mathrm{Zn}$ \\
\hline Resource (A) & $18.66^{\mathrm{b}}$ & $185.49^{b}$ & $35.76^{b}$ & $231.78^{b}$ & $22.95^{\mathrm{a}}$ & $0.22^{\mathrm{a}}$ & $0.57^{b}$ & $0.03^{a}$ & $0.37^{a}$ \\
\hline Culture & $20.21^{\mathrm{a}}$ & $196.29^{a}$ & $39.09^{a}$ & $247.84^{a}$ & $24.33^{a}$ & $0.23^{\mathrm{a}}$ & $0.84^{\mathrm{a}}$ & $0.03^{\mathrm{a}}$ & $0.38^{a}$ \\
\hline \multicolumn{10}{|l|}{ Wild } \\
\hline \multicolumn{10}{|l|}{ Size (B) } \\
\hline $100-150 \mathrm{~g}$ & $17.09^{d}$ & $180.67^{c}$ & $31.84^{\mathrm{b}}$ & $225.96^{c}$ & $23.10^{a}$ & $0.21^{\mathrm{a}}$ & $0.71^{\mathrm{a}}$ & $0.03^{\mathrm{a}}$ & $0.40^{\mathrm{ab}}$ \\
\hline $151-250 \mathrm{~g}$ & $18.40^{c}$ & $183.49^{b c}$ & $37.65^{a}$ & $236.53^{b c}$ & $23.54^{a}$ & $0.24^{\mathrm{a}}$ & $0.71^{a}$ & $0.03^{a}$ & $0.35^{\mathrm{b}}$ \\
\hline $251-500 \mathrm{~g}$ & $20.60^{b}$ & $195.80^{\mathrm{ab}}$ & $40.06^{a}$ & $241.45^{\mathrm{b}}$ & $24.63^{a}$ & $0.21^{\mathrm{a}}$ & $0.73^{a}$ & $0.03^{a}$ & $0.34^{b}$ \\
\hline$>500 \mathrm{~g}$ & $21.65^{\mathrm{a}}$ & $203.61^{a}$ & $40.15^{\mathrm{a}}$ & $255.29^{a}$ & $23.31^{a}$ & $0.24^{\mathrm{a}}$ & $0.68^{a}$ & $0.03^{\mathrm{a}}$ & $0.43^{\mathrm{a}}$ \\
\hline \multicolumn{10}{|l|}{ P-value } \\
\hline A & $<0.001$ & 0.030 & 0.009 & 0.001 & 0.066 & 0.312 & $<0.001$ & 0.596 & 0.671 \\
\hline B & $<0.001$ & 0.009 & $<0.001$ & 0.001 & 0.436 & 0.217 & 0.908 & 0.541 & 0.031 \\
\hline \multirow[t]{2}{*}{$A x B$} & 0.746 & 0.508 & $<0.001$ & 0.053 & 0.409 & 0.135 & 0.263 & 0.864 & 0.145 \\
\hline & & Mine & & & & & & & \\
\hline $\operatorname{SEM}( \pm)$ & 0.378 & 68.856 & 4.124 & 53.510 & 1.666 & 0.001 & 0.006 & 0.001 & 0.002 \\
\hline CV (\%) & 4.162 & 5.721 & 7.140 & 4.014 & 7.183 & 15.280 & 14.473 & 13.911 & 13.766 \\
\hline
\end{tabular}

Page 5/12 
The daily value (DV) of lipid, cysteine, $n-6+n-3$ fatty acids and calcium was $<25 \%$ and protein, valine, phosphorus and selenium were between $25-50 \%$. Isoleucine, leucine, lysine, phenylalanine and threonine showed a range of 50-100\%, whereas it crossed $>100 \%$ for methionine and EPA + DHA (Fig. 3). The DV was increased by $3.71,3.03,1.04,0.78,5.63$ and $2.78 \%$ for lipid, phenylalanine, threonine, tryptophan, valine and n-3 $+n-6$ fatty acids, respectively, and was decreased by $0.57,1.01,0.45,2.97,7.12,10.18,0.26,1.8$ and $3.21 \%$ for protein, cystine, leucine, lysine, methionine, EPA + DHA, calcium, phosphorus and selenium in wild caught fish compared to the cultured species, whereas no difference was noticed for isoleucine between the resources (Fig. 4). The result of DV of fish with the varied size has shown that the fish with a body weight of $>500 \mathrm{~g}$ had a higher DV for lipid, lysine, methionine, EPA + DHA, n-3 + n- 6 fatty acids, calcium and phosphorus, while cysteine and selenium were high in 251-500 g group. The DV of protein, isoleucine, leucine, phenylalanine, threonine and tryptophan found to be high in fish with 151-250 $\mathrm{g}$ weight and the group of 100-150 $\mathrm{g}$ showed a higher value for valine.

\section{Discussion}

Nutrient composition of fish, collected from wild and culture, is greatly varied in general. Because in intensive culture, fish are provided with nutrient dense compounded feeds that enables them to deposit large reserves of nutrients, in particular lipids. In contrast, considerable changes occurred in environmental condition fluctuates the availability and composition food that would affect the nutrient composition of wild fish ${ }^{20}$. In addition to food/feed, Piggott and Tucker $^{21}$ listed some other factors influencing the nutrient composition of fish such as species, genetics, size, reproductive status and environmental characteristics. In our study, the moisture content of wild fish was observed to be the highest compared to the cultured ones and was drastically reduced with increasing body size. This result is in agreement with the findings of Alasalvar et al ${ }^{2}$, who found higher moisture content in the wild caught sea bass than the cultured fish. In the present study, muscle protein content of $M$. cephalus did not vary between the resources. Similarly, size variation had no effect on the protein level. This result is corroborated with the finding of Nettlon and Exler ${ }^{22}$ in channel catfish, coho salmon and rainbow trout. In contrast, a slight variation in protein content was observed between wild and cultured yellow perch ${ }^{17}$. The difference in protein content might be due to the variation in environmental conditions, species, size, sex of the individual animals and their reproductive status ${ }^{14}$.

In the present study, the muscle tissue of the cultured $M$. cephalus contained higher lipid content than the wild caught fish. This is in agreement with earlier reports that have shown that the level of lipid tend to be lower in fish collected from wild compared to cultured individuals of the same species, such as yellow perch $^{17}$, turbot ${ }^{23}$, sea bream ${ }^{24}$, and silver pomfret ${ }^{25}$. The difference in muscle lipid content is most likely due to the result of dietary differences ${ }^{17}$. Grigorakis et $\mathrm{al}^{26}$ stated that the higher energy consumption would also be a reason for the storage of high lipid in cultured fish than the wild ones. The reduced activity of cultured fish than the wild fish would also influence the body lipid ${ }^{2}$. In addition, possible periods of starvation that encountered by wild fish might lead to reduce the lipid content of their body, which is not much occurred with cultured fish ${ }^{27}$. Morishita et al ${ }^{15}$ observed a higher muscle lipid content in cultured sea bream with increasing body weight and the same is corroborated in the present investigation, indicating that this as an intrinsic physiological trait. Rheman et $\mathrm{al}^{28}$ suggested that this would also be related to reproductive physiology of the fish. A similar observation has been made in sea bass ${ }^{29}$ (Poli et al., 2001). But in contrast, Giogios et $a^{30}$ observed a lower lipid with higher body size and a higher lipid with a lower body size of cultured meagre fish. This difference would be attributed to a variation in lipid metabolism and feed offered during the culture. In most of the earlier studies $2,17,23,24$, an inverse relationship was observed between the moisture and lipid content, while Zhao et $\mathrm{al}^{25} \mathrm{did}$ not find the same relationship in silver pomfret and stated that this might be because of silver pomfret is a non-fatty fish and the sample tested by the authors was originated by pooling five fishes together. Though, $M$. cephalus, used in the present study, is also considered as a non-fatty fish and though the analysis was done by pooling six fishes together in the present investigation, still observed an inverse relationship. Total ash content was significantly higher in wild fish compared to the cultured fish and is corroborated with our earlier findings ${ }^{9,14}$. In contrast, Alasalvar et $\mathrm{al}^{2}$ and Sharma et al ${ }^{31}$ reported no significant difference in ash content of sea bass and rohu, respectively sourced from culture and wild. The gross energy content was greatly varied between the sources (110.12-133.03 Kcal/100 g) and size groups (107.46-145.27 Kcal/100 g), which mainly related to the lipid content of fish as evidenced in the present study by a direct correlation between lipid and energy (Table 1).

It is essential to have adequate knowledge on amino acid content of fish protein to establish its nutritional value, as the nutritional quality of protein is mainly depending on EAA. Fish protein has a greater satiety effect than other animal proteins like chicken, beef, etc., with cheaper price ${ }^{7}$. The depicted values of amino acids in the present study was almost resembled to those presented by Mai et $\mathrm{al}^{32}$, who compared the amino acid composition of different fin-fishes, like white sucker, burbot, black crappie, rainbow trout, walleye pike and yellow perch. Of all the EAA, leucine found to be high and was in the range of 1.57-

$1.64 \%$ (wet weight basis). Etzel ${ }^{33}$ documented that leucine is mainly responsible for muscle protein synthesis and later, its therapeutic effect in various stress conditions of burn, trauma and sepsis is reported by De Bandt and Cynober ${ }^{34}$. Followed by leucine, M. cephalus had higher content of lysine (1.50-1.55\% wet weight basis) and is agreed by Zhao et $\mathrm{al}^{25}$ in Pomfret. Iqtidar et $\mathrm{al}^{35}$ reported that lysine is one of the most limiting amino acids in cereal-based diets given to children and is extensively required for optimal growth, hence it is suggested fish as an optimal supplement for cereal-based diets. Methionine plays a vital role in treating Parkinson's disease, liver disorder and schizophrenia, which would also help in the treatment of alcoholism, allergies, asthma, drug withdrawal, poisoning, particularly eliminating copper, radiation side effects, etc., ${ }^{14}$ and was ranged from $0.74-0.81 \%$ in $M$. cephalus. Arginine was the second highest EAA in the muscle portion of $M$. cephalus, which is mainly considered as a precursor for the biological synthesis of nitric acid and play an important role in neurotransmission, blood clotting and blood pressure maintenance. The disease of sepsis, preeclampsia, erectile dysfunction and anxiety was much recovered with the supplementation of arginine. Isoleucine, phenylalanine, threonine and valine had a variety of roles in human nutrition mainly in chronic renal failure and nervous system disorders ${ }^{26}$ and were found to be around $1 \%$ in both wild and cultured $M$. cephalus. Liao et al ${ }^{37}$ documented the necessity of histidine in the growth and repair of tissues, myelin sheaths maintenance and to remove heavy metals from the body. Similarly, tryptophan acts as a precursor for different neurotransmitters like serotonin, dopamine and nor-dopamine and was in the range of $0.28-0.29 \%$ in our study. 
Though NAA are synthesized de nova, they would also play a crucial role metabolically as in EAAs, especially in the regulatory process of gene expression, micro-RNA levels, metabolism, innate and cell mediated response ${ }^{38}$. Deutz et al ${ }^{39}$ reported that during critical illness, the effluxed glutamic acid from muscle serves as an important carrier of nitrogen as ammonia in the splanchnic area and immune system, which alone contributed more than $30 \%$ in total of NAA in our study. However, no significant difference was observed in muscle composition of both EAA and NAA, indicating that the protein content in M. cephalus was well balanced in amino acid composition, in particular EAA and is of high quality, irrespective of the resources and size. This result is corroborated with the findings of Gonzalez et $\mathrm{al}^{17}$ for the EAA content of wild and cultured yellow perch, but not for NAA and who reported significantly higher values for alanine, serine and tyrosine in wild caught yellow perch. Contrary, Zhao et $\mathrm{al}^{25}$ reported significant differences for all the EAA except arginine between wild and cultured silver pomfret and who found lower values in cultured fish than the wild ones. In relation to identifying the quality of protein, most of the studies are restricted in analysing only EAA. But in the present study, IP level was computed based on the FAO/WHO/UNU ${ }^{19}$ recommended values to elucidate that $M$. cephalus is how far better in providing protein/amino acid content in the human diet. It was found that IP level for all the calculated EAA was higher in $M$. cephalus compared to the recommended values except valine, indicating that $M$. cephalus is of good source in providing protein/amino acids irrespective of the resources even at varying size. Sarma et $\mathrm{al}^{40}$ found a marginal decrease in the IP value for histidine, leucine and threonine in golden mahseer, common snow trout and common carp, respectively as compared with the recommended level. Though the IP level of valine reduced than the recommended level in our study, the calculated EAAI has shown no significant difference among the EAA, including valine in both wild and cultured fish and also showed a positive correlation for EAAI between cultured and wild caught M. cephalus.

As a source of membrane constituents, energy, metabolic and signaling mediators, fatty acids, particularly n-3 PUFAs are recognized as essential nutrients for life. Aquatic species, primarily fish are generally characterized by high level of $n-3$ PUFAs, however, its composition influenced by many intrinsic and extrinsic factors. In our study, the level of saturated fatty acid (SFA) and monounsaturated fatty acid (MUFA) was significantly high in cultured $M$. cephalus than in wild caught fish, while the reverse was true for PUFA except C18:2c and $\mathrm{YC} 18: 3$ and as reflected in n-6/n-3 ratio, which shown that significantly lower n-6/n-3 ratio in wild compared to cultured fish, indicating that marine environment would have an excellent source for $n-3$ rich foods and which might be lower in intensive culture system. This result is greatly in agreement with those previously reported by Zhao et $\mathrm{al}^{4}$. In contrast, Alasalvar et $\mathrm{al}^{2}$ found the reverse trend in sea bass, who reported about 29.2 and $33.4 \%$ of SFA in cultured and wild collected sea bass and the remaining quantity was shared by MUFA and PUFA. But in the present study, SFA was about $50.7 \%$ in cultured fish and almost similar level was observed for wild fish (49.6\%). C16:0 was about > 70\% of the total SFA content of both cultured and wild $M$. cephalus and was significantly higher in cultured than in wild fish, which might be attributed to the usage of supplementary feed containing higher C16:0. Similar results have also been reported in sea bass ${ }^{2}$, crappie ${ }^{16}$, rohu ${ }^{31}$ and sturgeon $^{41}$. In MUFA, C18:1 was found as a major one in the both the fish and was significantly higher in cultured fish than that of wild ones. Similarly, C18:2c found to be ten-times higher in cultured M. cephalus compared to its wild counterpart, which is due to its dominance in compounded feed used for intensive culture ${ }^{26}$. Among n- 3 series, both EPA and DHA had no much variation like other fatty acids between the wild caught and cultured fish, indicating that both the fish are of good sources for these fatty acids. However, a marginal increase was noticed in wild fish than the cultured ones, but the difference was insignificant for DHA. A great variation was noticed in C20:4 and was much higher in wild fish $(170.36 \mathrm{mg} / 100 \mathrm{~g})$ than in cultured ones $(60.44 \mathrm{mg} / 100 \mathrm{~g})$. A similar result was found by Gonzalez et al ${ }^{17}$ in yellow perch and who suggested that this might be due to the dietary effect and saturation and/or elongation mechanisms. Similarly, the highest concentration of aC18:3 was observed in wild fish than in culture, which could be attributed to the type of food, in which $M$. cephalus is exposed in the wild such as insect larvae, algae, crustacean that are rich in aC18: $3^{42}$.

Simopoulos ${ }^{8}$ documented that the ratio of $1-2: 1$ for $n-6 / n-3$ fatty acids is being considered as an ideal level for beneficial health, while the Department of Health of United Kingdom recommends that this level might be up to 4:1. Whereas the Western diets provide n-6/n-3 ratio of around 15-25:1, which would be a reason for occurring various common health disorders like coronary heart disease and cancer. McDanniel et al ${ }^{43}$ suggested an approach, whereby consuming a higher dietary quantity of n-3 PUFAs, in particular C20:5 and C22:6 would be helpful in normalizing n-6/n-3 ratio. In our study, this ratio was 2.21:1 in cultured fish and was significantly low in wild caught fish (0.76:1), while it was in the range of 1.35-1.81:1 among the fish containing different body weight. All the values in our study were within the recommended values, indicating that $M$. cephalus could be considered as an optimal food source. Similarly, the DHA/EPA ratio seems to be lower in wild caught fish compared to cultured fish and the same was found in halibut fish ${ }^{44}$, sea bream ${ }^{45}$ and cat fish and tilapia ${ }^{46}$. In our study, all the fatty acids were gradually increased with increasing body size. However, the rate of increasing was not same among all the size groups. The proportion of the increase was almost similar between $100-150 \mathrm{~g}$ and $151-250 \mathrm{~g}$ groups as well as between $151-250 \mathrm{~g}$ and $250-500 \mathrm{~g}$ groups, while the increase was almost doubled in the fish categorized under $>500 \mathrm{~g}$. The similar variations in fatty acids in relation to fish size have been reported in gold-spot mullet ${ }^{14}$, rainbow trout ${ }^{47}$ and gilthead sea bream ${ }^{48}$. Kiessling and Kiessling ${ }^{49}$ suggested that the relative variations on fatty acid composition with varied body weights could be attributed to the selective aerobic phosphorylation of fatty acids into the mitochondria of muscle tissue. The selective mobilisation of fatty acids to the reproductive organs in larger fish would also be a reason for the same ${ }^{50}$. In contrast, Ghomi and Nikoo ${ }^{51}$ observed higher level for $\mathrm{C} 18: 1, \mathrm{C} 18: 2$ and $\mathrm{C} 18: 3$ in small size fish of sturgeon roe than the larger one.

Mineral content of fish is influenced by both diet and environment, especially in intensive culture and would also have an influence on flavor. In addition, deficiency of essential minerals in the diet might lead to improper enzyme-mediated metabolic functions, organ malfunctions and chronic disease. In our study, all the macro elements differed among the treatments except magnesium. Wild caught $M$. cephalus contained higher level of calcium, phosphorus, sodium and potassium than the cultured fish, while no significant difference was noticed for magnesium. Contrary, Gonzalez et al ${ }^{17}$ reported a higher concentration of magnesium, phosphorus, calcium and potassium in cultured yellow perch than that of its wild counterpart and the reverse was true for sodium. Whereas, micro elements were not affected except for iron. This result is agreed by Alasalvar et al ${ }^{2}$ in sea bass, however, a higher level of zinc was reported in cultured eel ${ }^{52}$. A linear relationship was observed in macro elements against fish body weight. Environmental conditions like water chemistry, salinity, temperature and contaminants would also responsible for the change in mineral composition ${ }^{2}$. Indian Council of Medical Research farms a simple recommended daily allowance guideline based on the FAO/WHO/UNU ${ }^{19}$ guideline to calculate the daily value (DV\%) of food. Dayal et al ${ }^{53}$ reported that food 
with $>70 \%$ DV rated as outstanding and those had $50-70,25-50,10-25 \%$ are categorized as excellent, very good and good, respectively, while if it falls $<10 \%$ is considered as poor. According to this, lysine, methionine, threonine, tryptophan and EPA + DHA were considered as outstanding nutrients in both wild and cultured M. cephalus. Similarly, isoleucine, leucine, phenylalanine and valine were grouped under the excellent category. Protein, phosphorus and selenium were categorized as very good. A similar trend was noticed among the size groups. Cultured $M$. cephalus contained a higher DV for lipid, phenylalanine, threonine, tryptophan, valine and n-3 + n- 6 fatty acids, whereas protein, cysteine, leucine, lysine, methionine, EPA + DHA, phosphorus and selenium were high in wild caught $M$. cephalus.

In conclusion, muscle of both cultured and wild $M$. cephalus is of good sources of protein with balanced amino acids, in particular EAA irrespective of the size groups. However, an important difference is found in some of the quality of lipid, fatty acid and macro mineral composition and they are influenced by both resources and size. In addition, the results of the present study indicate that $\mathrm{M}$. cephalus contains higher ideal protein compared to FAO/WHO/UNU recommended level with a good daily value for most of the nutrients. Our results suggest that despite of the changes in nutrient content, both wild and cultured $M$. cephalus fall under the category of nutrient rich fish and would be an effective and healthy food material.

\section{Methods}

Different size group (100-150 g, 151-250 g, 251-500 g and > 500 g) of M. cephalus specimens of cultured and wild were sourced from brackishwater fish farm at Nagayalanka ( $15.945^{\circ} \mathrm{N} 80.918^{\circ} \mathrm{E}$; Diviseema region) and Krishna River, respectively of Krishna district, Andhra Pradesh, India. Handling of animals in the present study complied with the current animal welfare laws in India and was in accordance with the relevant guidelines and regulations of the CPCSEA (Committee for the Purpose of Control and Supervision of Experiments on Animals), Ministry of Fisheries, Animal Husbandry and Dairying, Govt. of India, on care and use of animals in scientific research. This study was undertaken with approval of the Institute Animal Ethics Committee (IAEC), ICAR-Central Institute of Brackishwater Aquaculture, Chennai, India (F.No. SPA/Dir/5-90. Dated: 07.04.2014). Each group has been designed to contain six fishes with three replications. After dressed, skin and bone were removed from all the fishes. Boneless muscle tissues were collected from both dorsal and ventral areas and stored at $-20^{\circ} \mathrm{C}$ until analysis. Proximate composition of was determined by AOAC ${ }^{54}$ methods. The gross energy of samples was tested using a semi bomb calorimeter (Parr-1425). Amino acid profiles were analysed using pre-column HPLC gradient system (Shimadzu Corp, LC-30AD) after hydrolysing the samples with $6 \mathrm{~N}$ hydrochloric acid in a sealed tube filled with nitrogen for $22 \mathrm{~h}$ at $110^{\circ} \mathrm{C}$ in a vacuum oven ${ }^{55}$. Individual amino acids were separated by YMC-Triart $\mathrm{C} 18, \mathrm{RRH}(1.8 \mu \mathrm{m}, 2.1 \times 100 \mathrm{~mm})$ column after derivatization with mercaptopropionic acid, 0-phthalaldehyde and fluorenylmethoxycarbonyl chloride. A gradient elution using phosphate buffer ( $20 \mathrm{mmol}$ as mobile phase A) and combination of acetonitrile:methanol:water ( $45: 40: 15$ as mobile phase B) at the flow rate of $0.3 \mathrm{ml} / \mathrm{min}$ was used. The gradient was changed by increasing mobile phase B concentration at the rate of $11-13 \%$ at $3 \mathrm{~min}, 31 \%$ at $5 \mathrm{~min}, 37 \%$ at $15 \mathrm{~min}, 70 \%$ at $20 \mathrm{~min}$ and $100 \%$ at $25 \mathrm{~min}$. Amino acids were qualified and quantified by a fluorescent detector (RF-20AXS) using the amino acid mixer as an external standard (Sigma Aldrich, Cat. No: AAS18) and nor-leucine as an internal standard. Tryptophan, being labile to acid hydrolysis, was measured after alkali hydrolysis using a spectrophotometric method at $500 \mathrm{~nm}^{56}$. Essential amino acid index (EAAl) was calculated based on the ideal protein/amino acid level recommended by $\mathrm{FAO} / \mathrm{WHO} / \mathrm{UNU}^{19}$.

Lipid was extracted using a combination of organic solvent (chloroform and methanol at 2:1 ratio) and the process of saponification followed by esterification was done according to Metcalfe et al ${ }^{57}$. FAMEs were subsequently analysed using a gas chromatograph (GC-2014 Shimadzu) on a RTX-Wax Capillary Column ( $100 \mathrm{~m}$ length $\times 0.25 \mathrm{~mm}$ I.D $\times 0.2 \mu \mathrm{m}$ film thickness). Nitrogen was used as the carrier gas at a linear velocity of $20.9 \mathrm{~cm} / \mathrm{s}$ with $3 \mathrm{ml} / \mathrm{min}$ of purge flow. The oven temperature was held at $100^{\circ} \mathrm{C}$ for $4 \mathrm{~min}$ and increased to $225^{\circ} \mathrm{C}$ at the rate of $3^{\circ} \mathrm{C} / \mathrm{min}$ and held for $5 \mathrm{~min}$ and further increased to $240^{\circ} \mathrm{C}$ at the rate of $1^{\circ} \mathrm{C} / \mathrm{min}$. The operating temperature for injection ports and flame ionization detector was 225 and $250^{\circ} \mathrm{C}$ respectively. Individual fatty acids were identified by comparing with the retention times of 37 Component FAME Mix (Supelco-Sigma). Tridecanoic acid methyl ester (C13:0, Supelco-Sigma, USA) was used as an internal standard to calculate fatty acid content in the sample (mg/100 g). Mineral composition was estimated according to the method of Jannathulla et al ${ }^{58}$. Briefly, a gram of sample was digested with $6 \mathrm{ml}$ of $\mathrm{HNo}_{3}$ and $2 \mathrm{ml}$ of $\mathrm{H}_{2} \mathrm{O}_{2}$ in microwave digestion system (Anton Paar). All digested samples were analysed in triplicates using inductively coupled plasma-optical emission spectrometry (ICP-OES) in an instrument of Agilent-5100, using the 5.2 software. The analytical measurements were made with an autosampler equipped with a peristaltic pump, across-flow nebulizer (coupled to a double-pass spray chamber) and Quartz central torch tube injector with an internal diameter of $2 \mathrm{~mm}$. Certified reference material, ICP multi-element standard solution (10 mg/l Merck), was used for calibration.

The statistical package of SPSS ver.16.0 for Windows was used to assess the significant differences between the means of experimental data according to a two-way analysis of variance (ANOVA) using a $2 \times 4$ factorial design with two different factors such as resources (culture and wild) and size (100-150 g, 151$250 \mathrm{~g}, 251-500 \mathrm{~g}$ and $>500 \mathrm{~g}$ ). The descriptive statistical measures were calculated for the two main factors and their interactions. For this, post-hoc was done with Tukey's test and differences were considered significant when $\mathrm{P}<0.05$. Regression analysis was performed to find a correlation on EAAl between the resources irrespective of the size groups. Prior to statistical evaluation, data were checked for homogeneity of variances after ascertaining normal distribution.

\section{Declarations}

\section{Acknowledgements}

The authors are thankful to the Fisheries Division, ICAR, New Delhi, India for the financial support through Outreach Projects on Nutrient Profiling and Evaluation of Fish as a Dietary component and Fish Feeds. The authors also express their sincere thanks to progressive aquafarmer Mr. T. Raghusekar for providing facilities to conduct culture demonstration in his farm.

\section{Authors contributions}


J.S.D. was responsible for the study design and written the manuscript, R.J. analyzed all the parameters, K.A. did statistical analysis, K.P.K.V. helped for analysis and to write this manuscript, K.K.V. reviewed the data and the manuscript.

\section{Competing interest}

The authors declare no competing interest.

\section{Additional information}

Correspondence and request for materials should be addressed to J.S.D.

\section{References}

1. Reksten, A. M., Somasundaram, T., Kjellevold, M., Nordhagen, A., Bokevoll, A., Pincus, L. M., Rizwan, A. A., Mamun, A., Thilsted, S. H., Htut, T. \& Aakre, I. Nutrient composition of 19 fish species from Sri Lanka and potential contribution to food and nutrition security. Food Compos. Anal. 5, 103508 (2020).

2. Alasalvar, C., Taylor, K. D., Zubcov, E., Shahidi, F. \& Alexis, M. Differentiation of cultured and wild sea bass (Dicentrarchus labrax): total lipid content, fatty acid and trace mineral composition. Food Chem. 79, 145-50 (2002).

3. Montano, N., Gavino, G. \& Gavino, V. C. Polyunsaturated fatty acid contents of some traditional fish and shrimp paste condiments of the Philippines. Food Chem.75, 155-158 (2001).

4. Zhao, F., Zhuang, P., Song, C., Shi, Z. H. \& Zhang, L. Z. Amino acid and fatty acid compositions and nutritional quality of muscle in the pomfret, Pampus punctatissimus. Food Chem. 182, 224-227 (2010).

5. "Protein and amino acid requirements in human nutrition," WHO Technical Report series 935, World Health Organization, Geneva, Switzerland (2007).

6. FAO/IFAD/WFP. The State of Food Insecurity in the World 2013-The Multiple Dimensions of Food Security, FAO, Rome, Italy (2013).

7. Mohanty, B., Mahanty, A., Ganguly, S., Sankar, T. V., Chakraborty, K., Rangasamy, A., Paul, B., Sarma, D., Mathew, S., Asha, K. K. \& Behera, B. Amino acid compositions of 27 food fishes and their importance in clinical nutrition. Amino Acids. 1-7 (2014).

8. Simopoulos, A. P. The importance of the ratio of omega-6/omega-3 essential fatty acids. Pharmacother. 56, 365-379 (2002).

9. Dayal, J. S., Ambasankar, K., Jannathulla, R., Kumaraguruvasagam, K. P., Kailasam, M. \& Vijayan, K. K. Polyculture of mullets in brack-ishwater using compounded feed: Proximate and mineral profiles in comparison with wild mullets. Indian J. Fish. 64, 50-57 (2017).

10. The State of world Fisheries and aquaculture, Rome (2020).

11. Tacon, A. G. Trends in global aquaculture and aquafeed production: 2000-2017. Fish. Sci. Aquacult. 28, $43-56$ (2020).

12. Aizen, J., Meiri, I., Tzchori, I., Levavi-Sivan, B. \& Rosenfeld, H. Enhancing spawning in the grey mullet (Mugil cephalus) by removal of dopaminergic inhibition. Comp. Endocrinol. 142, 212-221 (2005).

13. Jannathulla, R., Khan, H. I., Thulasi, D., Kathyayani, S., Ambasankar, K., Panigrahi, A., Muralidhar, M. \& Dayal, J. S. Feeding diets with graded levels of fermented soybean meal to Pacific whiteleg shrimp Penaeus vannamei (Boone, 1931): Effect on digestive enzymes, immune responses and carcass composition. Indian J. Fish. 66, 60-68 (2019).

14. Dayal, J. S., Ambasankar, K., Jannathulla, R., Kumuraguruvasagam, K. P. \& Kailasam, M. Nutrient and fatty acid composition of cultured and wild caught gold-spot mullet Liza parsia (Hamilton, 1822). Indian J. Fish. 66, 62-70 (2019).

15. Morishita, T., Uno, K., Araki, T. \& Takahashi, T. Comparison of the fatty acid compositions in cultured red sea bream differing in the localities and culture methods, and those in wild fish. Nippon Suisan Gakkai. 55, 847-852 (1989).

16. Grun, I. U., Shi, H., Fernando, L. N., Clarke, A. D., Ellersieck, M. R. \& Beffa, D. A. Differentiation and identification of cultured and wild crappie (Pomoxis) based on fatty acid composition. LWT-Food Sci. Technol. 33, 305-311 (1999).

17. Gonzalez, S., Flick, G. J., O’keefe, S. F., Duncan, S. E., McLean, E. \& Craig, S. R. Composition of farmed and wild yellow perch (Perca flavescens). Food Compos. Anal. 19, 720-726 (2006).

18. Chuang, J. L., Lin, R. T. \& Shiau, C. Y. Comparison of meat quality related chemical compositions of wild-captured and cage-cultured cobia. Mar. Sci. Technol. 18, 580-586 (2010).

19. FAO/WHO/UNU. Energy and protein requirements. Report of a joint FAO/WHO/ UNU Expert Consultation, World Health Organization technical report series 724. Geneva: WHO. pp. 121-123 (1985).

20. Orban, E., Nevigato, T., Masci, M., Di Lena, G., Casini, I., Caproni, R., Gambelli. L., De Angelis, P. \& Rampacci, M. Nutritional quality and safety of European perch (Perca fluviatilis) from three lakes of Central Italy. Food Chem. 100, 482-490 (2007).

21. Piggott, G. M. \& Tucker, B. W. Effects of technology on nutrition pp. 137-175 (1990).

22. Nettleton, J. A. \& Exler, J. Nutrients in wild and farmed fish and shellfish. Food Sci. 67, 257-260 (1992).

23. Serot, T., Gandemer, G. \& Demaimay, M. Lipid and fatty acid compositions of muscle from farmed and wild adult turbot. Int. 6, 331-343 (1998).

24. Cejas, J. R., Almansa, E., Jerez, S., Bolanos, A., Samper, M. \& Lorenzo, A. Lipid and fatty acid composition of muscle and liver from wild and captive mature female broodstocks of white sea bream, Diplodus sargus. Biochem. Physiol. 38, 91-102 (2004).

25. Zhao, F., Zhuang, P., Zhang, L. \& Shi, Z. Biochemical composition of juvenile cultured vs. wild silver pomfret, Pampus argenteus: determining the diet for cultured fish. Fish Physiol. Biochem. 36, 1105-1111 (2010). 
26. Grigorakis, K., Alexis, M. N., Taylor, K. A. \& Hole, M. Comparison of wild and cultured gilthead sea bream (Sparus aurata); composition, appearance and seasonal variations. J. Food Sci. Technol. 37, 477-484 (2002).

27. Haard, N. F. Control of chemical composition and food quality attributes of cultured fish. Food Res. Int. 25, 289-307 (1992).

28. Rheman, S., Islam, M. L., Shah, M. M., Mondal, S. \& Alam, M. J. Observation on the fecundity and gonadosomatic index (GSI) of grey mullet Liza parsia (Ham.). Biol. Sci. 2, 690-693 (2002).

29. Poli, B. M., Parisi, G., Zampacavallo, G., Mecatti, M., Lupi, P., Gualtieri, M. \& Franci, O. Quality outline of European sea bass (Dicentrarchus labrax) reared in Italy: shelf life, edible yield, nutritional and dietetic traits. 202, 303-315 (2001).

30. Giogios, l., Grigorakis, K. \& Kalogeropoulos, N. Organoleptic and chemical quality of farmed meagre (Argyrosomus regius) as affected by size. Food Chem. 141, 3153-3159 (2013).

31. Sharma, P., Kumar, V., Sinha, A. K., Ranjan, J., Kithsiri, H. M. \& Venkateshwarlu, G. Comparative fatty acid profiles of wild and farmed tropical freshwater fish rohu (Labeo rohita). Fish Physiol. Biochem. 36, 411-417 (2010).

32. Mai, J., Shetty, J. K., Kan, T. M. \& Kinsella, J. E. Protein and amino acid composition of select freshwater fish. Agri. Food Chem. 28, 884-885 (1980).

33. Etzel, M. R. Manufacture and use of dairy protein fractions. Nutr. 134, 996S-1002S (2004).

34. De Bandt, J. P. \& Cynober, L. Therapeutic use of branched-chain amino acids in burn, trauma, and sepsis. Nutr. 136, 308S-313S (2006).

35. Iqtidar, A. \& Khalil, S. K. Protein quality of Asian beans and their wild progenitor, Vigna sublobata (Roxb). Food Chem. 52, 327-339 (1995).

36. Vuzelov, E., Krivoshiev, S., Ribarova, F. \& Boyadjiev, N. Plasma levels of branched chain amino acids in patients on regular hemodialysis before and after including a high-protein supplement in their diet. Folia Medica 41, 19-22 (1999).

37. Liao, S. M., Du, Q. S., Meng, J. Z., Pang, Z. W. \& Huang, R. B. The multiple roles of histidine in protein interactions. Cen. J. 7, 44-55 (2013).

38. Wu, G. Functional amino acids in growth, reproduction, and health. Nutr. 1, 31-37 (2010).

39. Deutz, N. E., Reijven, P. L., Athanasas, G. \& Soeters, P. B. Post-operative changes in hepatic, intestinal, splenic and muscle fluxes of amino acids and ammonia in pigs. Sci. 83, 607-614 (1992).

40. Sarma, D., Akhtar, M. S., Das, P., Das, P., Shahi, N., Ciji, A., Mahanta, P. C., Yengkokpam, S. \& Debnath, D. Nutritional quality in terms of amino acid and fatty acid of five coldwater fish species: implications to human health. Acad. Sci. Lett. 36, 385-391 (2013).

41. Chen, I. C., Chapman, F. A., Wei, C. L., Portier, K. M. \& O'keefe, S. F. Differentiation of cultured and wild sturgeon (Acipenser oxyrinchus Desotoi) based on fatty acid composition. Food Sci. 60, 631-635 (1995).

42. Steffens, W. Effects of variation in essential fatty acids in fish feeds on nutritive value of freshwater fish for humans. 151, 97-119 (1997).

43. McDaniel, J., Ickes, E. \& Holloman, C. Beneficial n-3 polyunsaturated fatty acid levels and n6: n3 ratios after 4-week EPA+ DHA supplementation associated with reduced CRP: a pilot study in healthy young adults. Res. Inflamm. 4, 59-68 (2013).

44. Olsson, G. B., Olsen, R. L., Carlehog, M. \& Ofstad, R. Seasonal variations in chemical and sensory characteristics of farmed and wild Atlantic halibut (Hippoglossus hippoglossus). 217, 191-205 (2003).

45. Grigorakis, K. \& Alexis, M. N. Effects of fasting on the meat quality and fat deposition of commercial-size farmed gilthead sea bream (Sparus aurata, L.) fed different dietary regimes. Nutr. 11,341-344 (2005).

46. Usydus, Z., Szlinder-Richert, J., Adamczyk, M. \& Szatkowska, U. Marine and farmed fish in the Polish market: Comparison of the nutritional value. Food Chem. 126, 78-84 (2011).

47. Kiessling, A., Pickova, J., Johansson, L., Asgard, T., Storebakken, T. \& Kiessling, K. H. Changes in fatty acid composition in muscle and adipose tissue of farmed rainbow trout (Oncorhynchus mykiss) in relation to ration and age. Food Chem. 73, 271-284 (2001).

48. Ballester-Lozano, G. F., Benedito-Palos, L., Navarro, J. C., Kaushik, S. \& Perez-Sanchez, J. Prediction of fillet fatty acid composition of market-size gilthead sea bream (Sparus aurata) using a regression modelling approach. 319, 81-88 (2011).

49. Kiessling, K. H. \& Kiessling, A. Selective utilization of fatty acids in rainbow trout (Oncorhynchus mykiss Walbaum) red muscle mitochondria. J. Zool. 71, 248-251 (1993).

50. Perez, M. J., Rodriguez, C., Cejas, J. R., Martin, M. V., Jerez, S. \& Lorenzo, A. Lipid and fatty acid content in wild white seabream (Diplodus sargus) broodstock at different stages of the reproductive cycle. Biochem. Physiol. 146, 187-196 (2007).

51. Ghomi, M. R. \& Nikoo, M. Fatty acid composition of Kutum Rutilus frisii kutum roe: the effect of fish size. World App. Sci. J. 11, 470-472 (2010).

52. Clavi, A. M., Allinson, G., Jones, P., Salzman, S., Nishikawa, M. \& Turoczy, N. Trace metal concentrations in wild and cultured Asutralian shrot-finned eel (Anguilla australis Richardson). Environ. Contam. Toxiol. 77, 590-596 (2006).

53. Dayal, J. S., Ponniah, A. G., Khan, H. I., Babu, E. M., Ambasankar, K. \& Vasagam, K. K. Shrimps-a nutritional perspective. Sci. 10, 1487-1491 (2013).

54. Official Methods of Analysis of Association of Analytical Chemists, $18^{\text {th }}$ edn. Association of Analytical Chemists, Benjamin Franklin Station, Washington DC (1997).

55. Finlayson, A. J. Amino acid recovering in the analysis of some feed samples. J. Plant Sci. 45, 184-188 (1964).

56. Sastry, C. S. P. \& Tammuru, M. K. Spectrophotometric determination of tryptophan in protein. Food Sci. Technol. 22, 146-147 (1985).

57. Metcalfe, L. D., Schmitz, A. A. \& Pelka, J. R. Rapid preparation of fatty acid esters from lipids for gas chromatographic analysis. Chem. $\mathbf{3 8}$, 514-515 (1966).

58. Jannathulla, R., Dayal, J. S., Chitra, V., Ambasankar, K. \& Muralidhar, M. Growth and carcass mineralisation of Pacific whiteleg shrimp Penaeus vannamei Boone 1931 in response to water salinity. Indian J. Fish 64, $22-27$ (2017). 
Figures

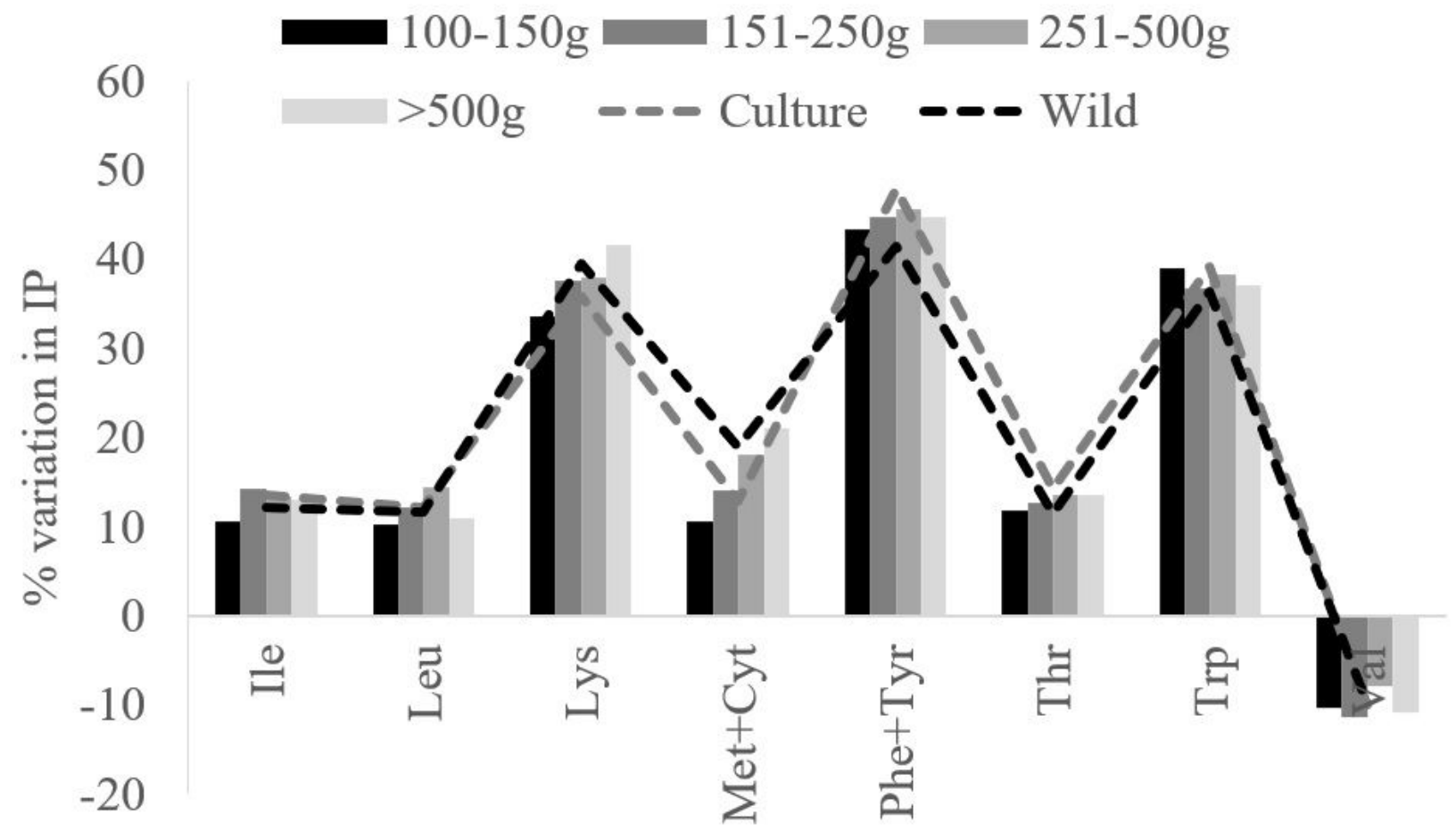

Figure 1

Percent variation of ideal protein (IP) level of M. cephalus collected from different resources with varied size groups.

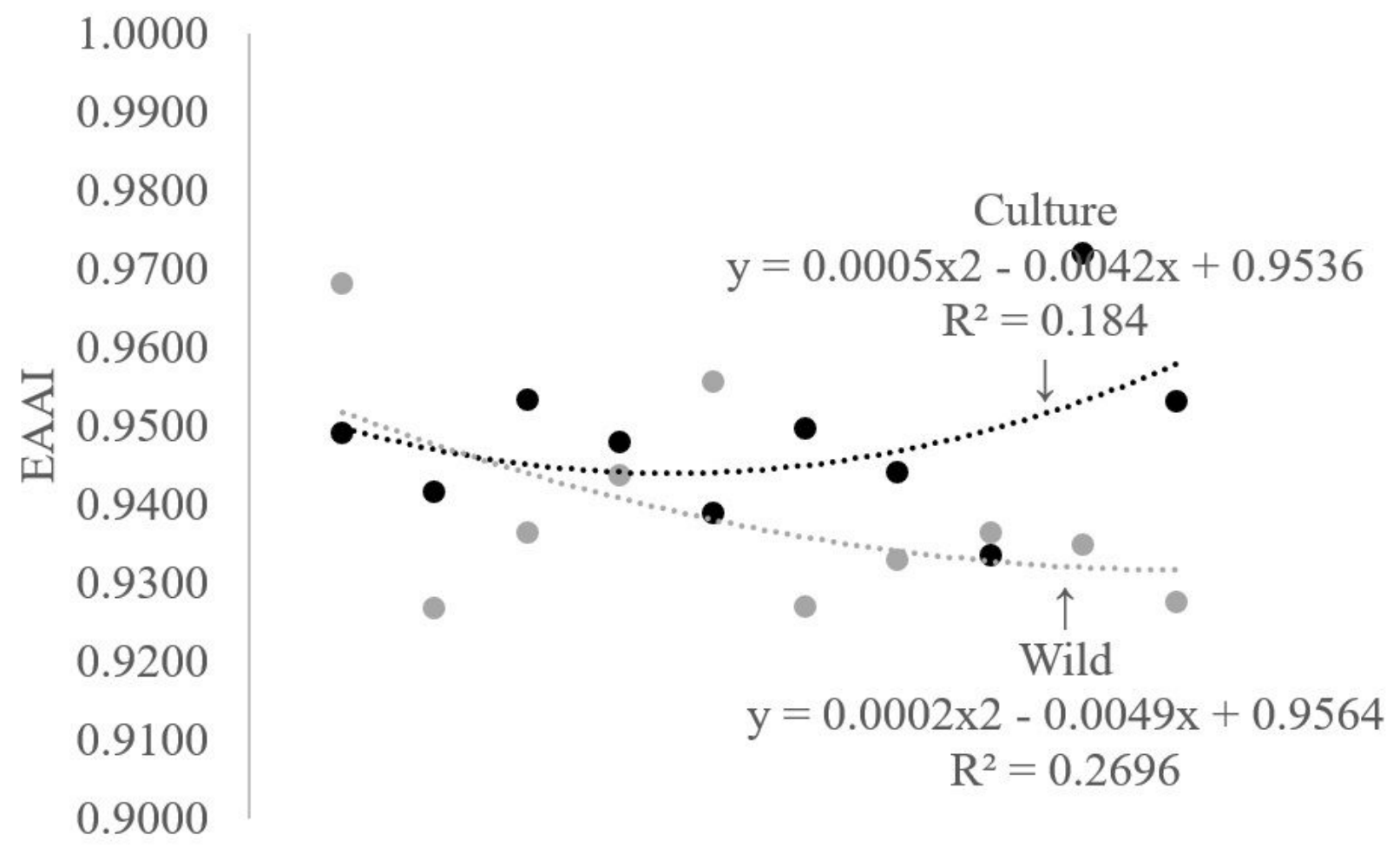




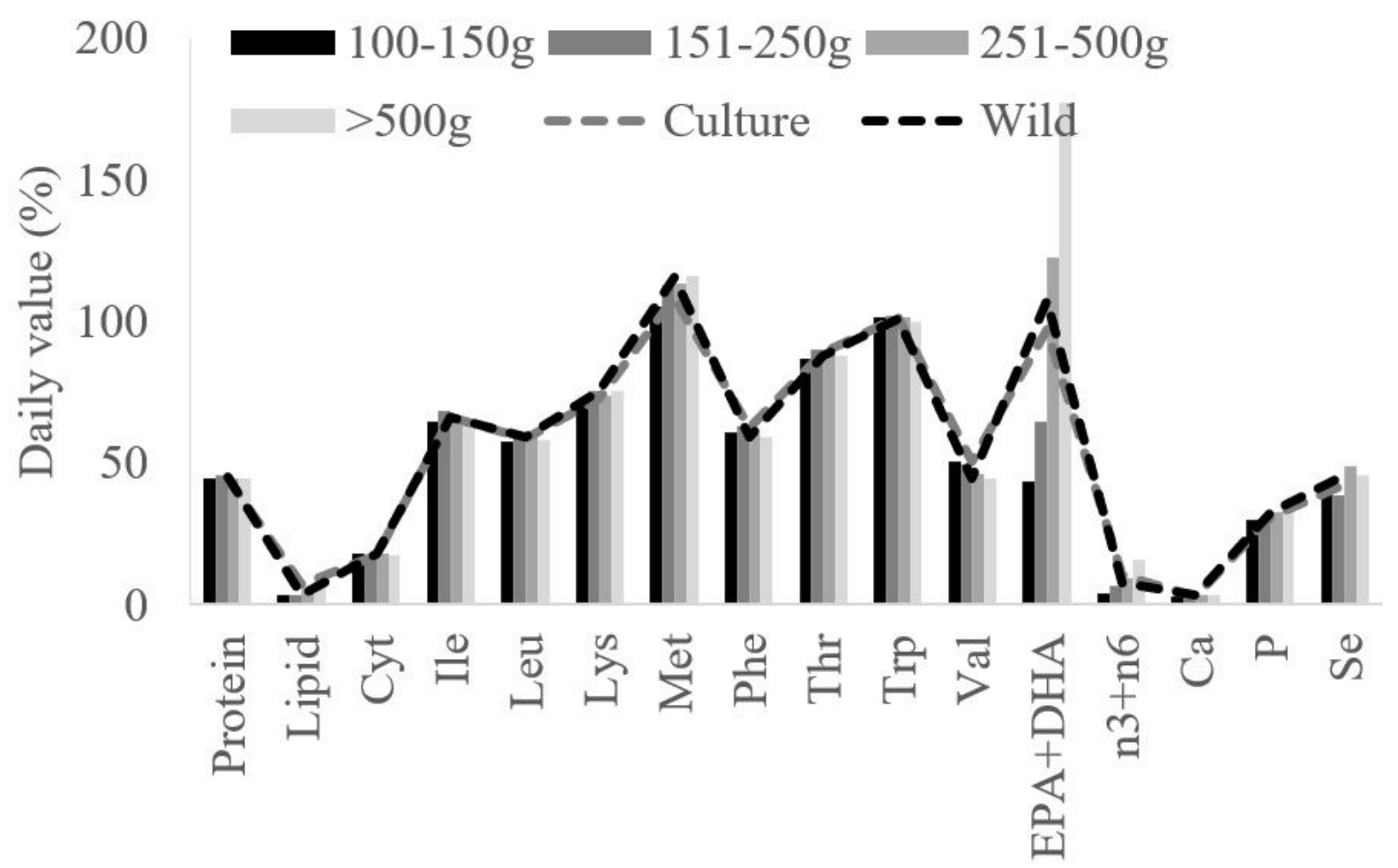

Figure 3

Daily value (\%) of one serving of $100 \mathrm{~g}$ of $\mathrm{M}$. cephalus collected from different resources with varied size groups.

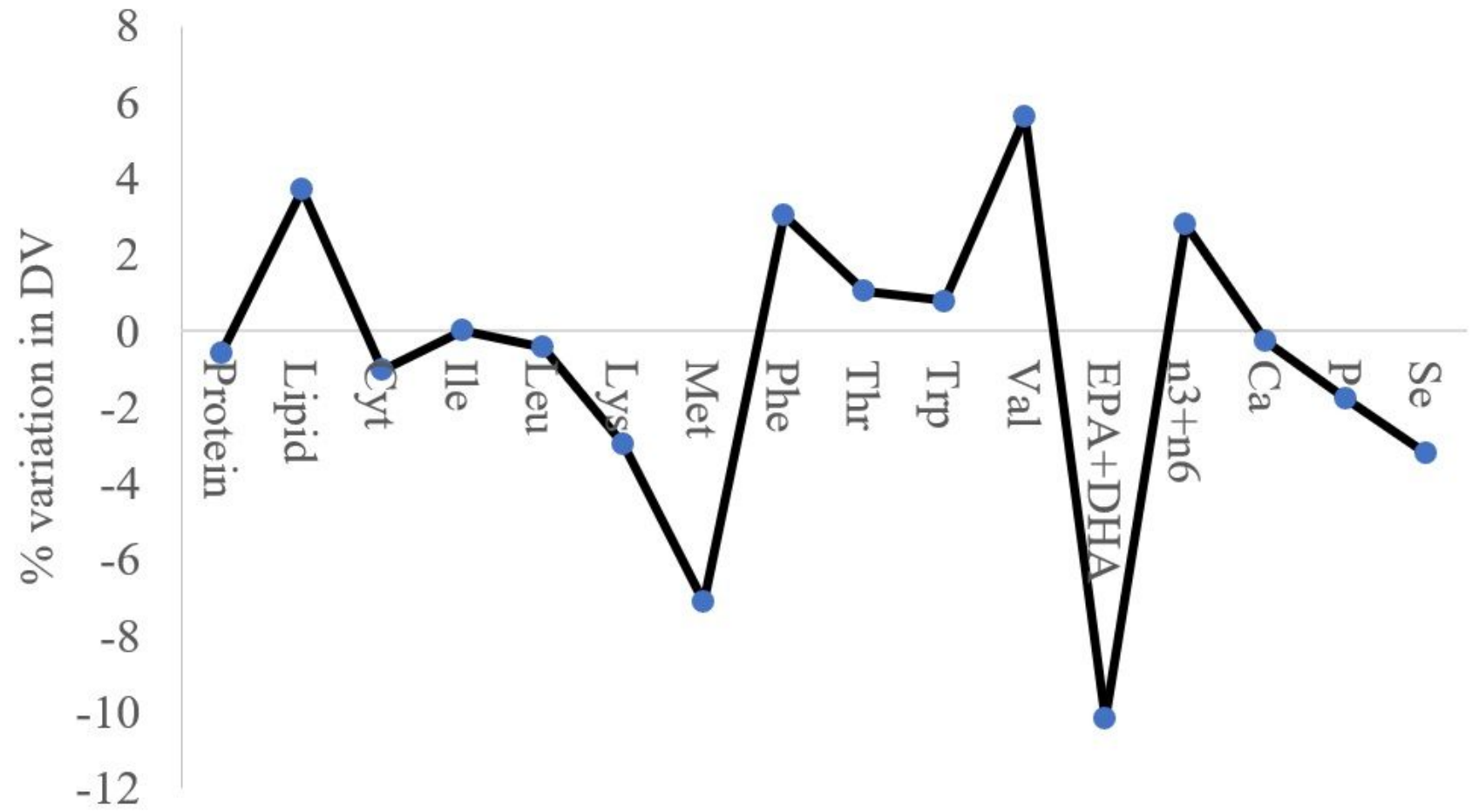

Figure 4

Percent variation of daily value (DV) between culture and wild collected M. cephalus irrespective of the size groups. 